National Marine

Fisheries Service

NOAA
Fishery Bulletin

a established in 1881 向
Spencer F. Baird

First U.S. Commissione of Fisheries and founder of Fishery Bulletin

\begin{abstract}
This study assessed the aging techniques and growth rates of river herring, the alewife (Alosa pseudoharengus) and blueback herring (Alosa aestivalis), in the tributaries of the Potomac River in northern Virginia. River herring are currently under moratoria in the Potomac River because of a lack of information about their populations. Ages determined from the use of otoliths and scales collected from river herring were compared to quantify aging bias and precision. For 2- and 3-year-old individuals, ages were commonly higher when derived from scales than when derived from otoliths. Length-at-age data were analyzed by using 9 growth models, and the best-fit-model was determined by using Akaike's information criterion (AIC). The outputs from the growth models were only slightly different, with differences of $10.6 \%$ and $10.5 \%$ in the AIC weights between best- and worst-fit models for alewife and blueback herring, respectively. Results from the use of a von Bertalanffy growth model indicate that alewife grew larger and faster than blueback herring $(P<0.0001)$ and that females grew larger and faster than males for both species $(P<0.0001)$. The findings of this study provide needed aging and growth information about 2 species within the Potomac River, where information about growth rates and population ages is limited.
\end{abstract}

Manuscript submitted 26 June 2018. Manuscript accepted 7 February 2019. Fish. Bull. 117:59-69 (2019).

Online publication date: 22 February 2019. doi: 10.7755/FB.117.1-2.7

The views and opinions expressed or implied in this article are those of the author (or authors) and do not necessarily reflect the position of the National Marine Fisheries Service, NOAA.

\title{
Growth of adult river herring that spawn in tributaries of the Potomac River in northern Virginia
}

\author{
C. J. Carroll Schlick \\ Kim de Mutsert \\ Email address for contact author: cjcschlick@gmail.com \\ Department of Environmental Science and Policy \\ George Mason University \\ Potomac Science Center \\ 650 Mason Ferry Avenue, Room 1305 \\ Woodbridge, Virginia 22191
}

The alewife (Alosa pseudoharengus) and blueback herring (Alosa aestivalis), collectively called river herring, were once important target species of commercial and recreational fisheries along the Atlantic coast of the United States and Canada. Returning to freshwater spawning grounds in early spring, river herring and other similar anadromous species were the targets of a thriving fishery after harsh winters for much of the northern Atlantic seaboard for centuries (Wharton, 1957; Fay et al. ${ }^{1}$; Jessop, 1994; Greene et al. ${ }^{2}$; ASMFC, 2012). Commercial landings of river herring declined by $98 \%$ in the United States from the 1950s (when detailed records were first kept) to the 1970 s, and average landings in the Chesapeake Bay plummeted 99\% or more

${ }^{1}$ Fay, C. W., R. J. Neves, and G. B. Pardue. 1983. Species profiles: life histories and environmental requirements of coastal fishes and invertebrates (midAtlantic)—alewife/blueback herring, 25 p. Div. Biol. Serv., U.S. Fish Wildl. Serv., FWS/OBS-82/11.9. U.S. Army Corps Eng., TR EL-82-4.

${ }^{2}$ Greene, K. E., J. L. Zimmerman, R. W. Laney, and J. C. Thomas-Blate. 2009. Atlantic coast diadromous fish habitat: a review of utilization, threats, recommendations for conservation, and research needs. Atl. States Mar. Fish. Comm. Habitat Manage. Ser. 9, 463 p. [Available from website.] from the 1970 s to 2010 (NRDC $\left.^{3}\right)$. Declines in populations of river herring throughout their geographical region have been attributed to overfishing and habitat degradation in spawning habitats; therefore, populations are termed depleted rather than overfished (Hightower et al., 1996; $\mathrm{NMFS}^{4}$; $\mathrm{NRDC}^{3}$ ). To promote the recovery of river herring, the Atlantic States Marine Fisheries Commission (ASMFC) established that commercial and recreational fisheries in any jurisdiction may not land river herring unless a sustainable fishery management plan has been approved starting in January 2012 (Greene et al. ${ }^{2}$; ASMFC, 2012).

In the stock assessment completed in 2017, the status of the alewife stock in the Potomac River was listed as stable, but the stock of blueback herring was listed as unknown (ASMFC, 2017). Data collection and

${ }^{3}$ NRDC (Natural Resource Defense Council). 2011. Petition to list alewife (Alosa pseudoharengus) and blueback herring (Alosa aestivalis) as threatened species and to designate critical habitat, 107 p. Nat. Resour. Defense Counc., Washington, D.C.

${ }^{4}$ NMFS (National Marine Fisheries Service). 2009. Species of concern: river herring (alewife and blueback herring) Alosa pseudoharengus and A. aestivalis, 8 p. Natl. Mar. Fish. Serv., Washington, D.C. 
monitoring are considered top priorities for management of river herring, with an emphasis on total catch (including bycatch), validation of age determination, determination of population sizes, and determination of the effectiveness of restoration efforts (ASMFC, 2012, 2017). Data on the populations of river herring in the Potomac River have been limited to indices of juvenile abundance and to surveys of adults by using electrofishing or push nets (Schlick, 2016; ASMFC, 2017). The catch per unit of effort for adults captured in the Potomac River by the District of Columbia Department of Energy and Environment has increased since 2012 for both species; however, the geometric mean of catch of juvenile river herring does not have the same clear trend in seining data collected by the District of Columbia Department of Energy and Environment and Maryland Department of Natural Resources (ASMFC, 2017). The Potomac Environmental Research and Education Center of George Mason University has reported an increase in river herring catch since 1988 in Gunston Cove, a small embayment of the Potomac River (Schlick, 2016; Jones et $\mathrm{al}^{5}$ ).

Whether habitat degradation or overfishing are the major contributors to the decline of these populations, data on the characteristics of spawning populations of river herring are needed to help manage them. Growth rates can change over time because of overfishing or degradation of spawning habitat and through natural variation over time (Heino, 1998; Law, 2000; Heino and Godo, 2002; Wang and Höök, 2009). Additionally, these characteristics can differ within populations throughout their geographical range, even in close proximity (Sheppard et al.6; Tuckey and Olney, 2010). For example, alewife had statistically higher growth rates in the Nemasket River, Massachusetts, than in 3 other rivers in Massachusetts (Sheppard et al. ${ }^{6}$ ). Fish fecundity is directly related to size, with larger individuals in a population producing more eggs per spawning event (Lake and Schmidt ${ }^{7}$ ). Therefore, body size and growth rates are important in population analyses. Updating growth parameters of the species after severe declines in the population is important for current stock assessment strategies.

\footnotetext{
5 Jones, R. C., K. de Mutsert, and A. Fowler. 2017. An ecological study of Gunston Cove 2016: final report, 181 p. Potomac Environ. Res. Educ. Cent., George Mason Univ., Fairfax, VA. [Available from website.]

6 Sheppard, J. J., P. D. Brady, M. P. Armstrong, and G. A. Nelson. 2010. Characterizing contemporary and historic age structure of alewives (Alosa pseudoharengus) in Massachusetts spawning runs: final report, 110 p. [Available from Mass. Div. Mar. Fish., 30 Emerson Ave., Gloucester, MA 01983.]

${ }^{7}$ Lake, T. R., and R. E. Schmidt. 1998. The relationship between fecundity of an alewife (Alosa pseudoharengus) spawning population and egg productivity in Quassaic Creek, a Hudson River tributary (HRM 60) in Orange County, New York. In Final reports of the Tiber T. Polgar Fellowship Program, 1997 (J. R. Waldman and W. C. Nieder,eds.), p. II1-24. Hudson River Foundation, NY. [Available from website.]
}

The von Bertalanffy growth function is the most commonly used model to describe the growth (in length or weight) of individuals within a fish population; however, for many species, the von Bertalanffy growth model is not the best fit (Quinn and Deriso, 1999; Katsanevakis and Maravelias, 2008; Haddon, 2011). Katsanevakis and Maravelias (2008) reported that the von Bertalanffy growth function was the best-fit model in $34.6 \%$ of 133 different data sets. A difference in the best-fit model between populations could be due to the parameters used in the model or the particular species not growing at an asymptotic rate, which is an assumption of the von Bertalanffy growth model (Katsanevakis and Maravelias, 2008). Today, multiple growth models can be constructed easily with the use of software programs; therefore, a useful way to determine the best-fit model is running multiple types of growth models (e.g., von Bertalanffy, Gompertz, and Richards) and then statistically comparing the growth parameters by using the Akaike's information criterion (AIC) (Burnham and Anderson, 2002; Katsanevakis and Maravelias, 2008).

Development of growth models is necessary for understanding population size and growth potential, information used to properly manage fisheries use, and can be achieved by using length-at-age data; however, length-at-age data for river herring have been used with little validation or standardization of aging techniques between scientists $\left(\mathrm{ASMFC}^{8}\right)$. Aging of river herring has been accomplished through reading annuli on whole otoliths or on scales under a dissecting microscope; however, validation with known ages of individuals has not been documented for river herring $\left(\mathrm{ASMFC}^{8}\right)$. Aging by reading scales is a nonlethal option but can result in less accurate age estimation because periods of minimal growth can result in false annuli on scales (Campana and Neilson, 1985; Beamish and McFarlane, 1987). Additionally, the methods developed by Cating (1953) for American shad (A. sapidissima) were the most cited methods for aging river herring by using scales until Duffy et al. (2011) reported that the transverse grooves on scales used in aging can vary over time and geographical range.

The goal of this study was to examine lengths, ages, and growth of adult river herring returning to tributaries of the Potomac River in 2007-2015 to spawn. The objectives to obtain this goal were to determine 1) the relationships between different measurements of length, 2) bias between using scales and using otoliths to estimate age, 3) the best-fit model by examining multiple growth models, and 4) growth parameters by using the best-fit model. Understanding length, age, and growth parameters is crucial for the determination of the reproductive capacity, potential restoration time

\footnotetext{
${ }^{8}$ ASMFC (Atlantic States Marine Fisheries Commission). 2014. 2013 river herring ageing workshop report, 88 p. Atl. States Mar. Fish. Comm., Washington, D.C. [Available from website.]
} 
line, and overall health of river herring populations, whose current statuses are unknown.

\section{Materials and methods}

\section{Study sites}

Adult river herring were sampled at 5 locations: Pohick Creek, Accotink Creek, Dogue Creek, Quantico Creek, and Cameron Run, all third-order tributaries that run through northern Virginia and drain into the Potomac River south of Washington, D.C. (Fig. 1). This stretch of the Potomac River is tidally influenced freshwater, which continues into the lower portions of each creek (Jones et al., 2008). River herring have been documented to spawn in each creek below the Virginia fall line (Jones et al. ${ }^{9}$; Schlick, 2016; Jones et al. ${ }^{5}$.

\section{Field methods}

Adults migrating upstream through Accotink Creek and Pohick Creek (Fig. 1) were sampled by blocking each creek for $24 \mathrm{~h}$ by using a hoop net with a mesh of $1.3 \mathrm{~cm}$ and snow fencing with a mesh of $5.1 \mathrm{~cm}$ once a week from midMarch through May from 2007 through 2015. Cameron Run was sampled the same way from 2013 through 2015 (Fig. 1). In 2007 and 2008, adult river herring were collected from Quantico Creek and Dogue Creek by electrofishing (Fig. 1). All captured adult alewife $(n=1707)$ and blueback herring $(n=1159)$ were counted and measured, and their sex was determined. Adults that did not survive capture (598 alewife and 304 blueback herring) were frozen unless dissection occurred within $48 \mathrm{~h}$ of capture. Adults were measured for wet weight in grams and for standard length (SL), fork length (FL), and total length (TL) in millimeters. Scales were collected, cleaned by using a mild detergent, and dried flat (ASMFC ${ }^{8}$ ). Sagittal otoliths were collected and stored dry.

\section{Laboratory methods}

Sagittal otoliths were cleaned of all fish debris by using water. Two separate readers viewed otoliths under a dissecting microscope on a black background by using reflected light following procedures outlined in the report of the ASFMC workshop on aging of river herring held in 2013 (ASMFC ${ }^{8}$ ). Samples were excluded from analysis when an age was not agreed upon. From each

\footnotetext{
${ }^{9}$ Jones, R. C., K. de Mutsert, and G. D. Foster. 2014. An ecological study of Hunting Creek 2013: final report, 113 p. George Mason Univ., Fairfax, VA. [Available from website.]
}

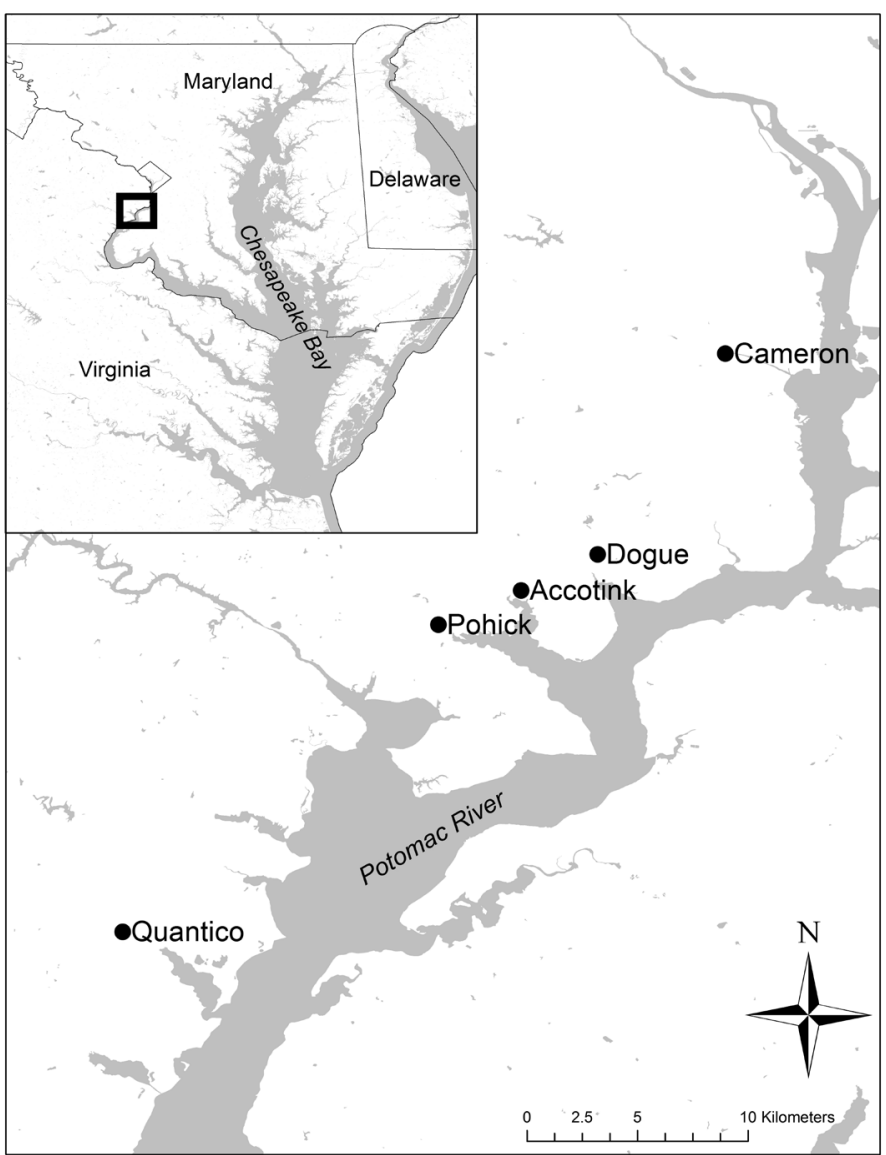

Figure 1

Map of locations where adult river herring, alewife (Alosa pseudoharengus) and blueback herring (Alosa aestivalis), were sampled from 2007 through 2015 within small tributaries that lead to the Potomac River in northern Virginia. There are 5 locations: Quantico Creek, Pohick Creek, Accotink Creek, Dogue Creek, and Cameron Run. Map data sources: U.S. Geological Survey, 1:250,000-scale Hydrologic Units of the United States; Esri, U.S. National Atlas Water Feature Lines.

fish, 5-6 scales were cleaned with water and a mild detergent; then they were sandwiched between 2 slides, examined, photographed by using a camera mounted on a dissecting microscope with transmitted light, and read for annuli (ASMFC ${ }^{8}$ ). Because river herring were captured during spawning season, the edges of otoliths and scales were counted as a year (Cating, 1953).

\section{Age validation}

It was assumed that ages from analysis of otoliths were more likely to be accurate than ages from analysis of scales because scales contain more false annuli and are more susceptible to environmental degradation (Campana and Neilson, 1985; Beamish and McFarlane, 1987; Besler, 1999). Additionally, readers agreed on 858 of 861 
otolith readings but on only 792 of 828 scale readings. Otolith readings were compared with scale readings to verify ages of scales by using age bias and precision analyses in RStudio ${ }^{10}$, vers. 1.0.153 (RStudio, Inc., Boston, MA) and the $\mathrm{R}$ package FSA, vers. 0.7.3 (Ogle, 2015). Plots of age bias were created by plotting ages agreed upon by otolith readers versus ages from scale readings to visually examine data for systematic bias in aging scales (Campana et al., 1995). Ages within the age-bias plot were analyzed by using a $t$-test to determine if ages from scales agree with ages from otoliths (Campana et al., 1995). To statistically test for symmetry, McNemar's test, Evans-Hoenig test, and Bowker's test were used to determine the differences around the main diagonal of the age-bias plot (Evans and Hoenig, 1998). Average coefficient of variation (ACV) was used to find the variability in ages determined by using ages from otoliths versus ages from scales (Campana, 2001).

\section{Statistical analyses}

Relationships between SL and FL, SL and TL, and FL and TL were estimated on the basis of linear regression analyses. Length-at-age data were used to determine growth curves in 9 different growth models: von Bertalanffy (von Bertalanffy, 1938), Gompertz (Gompertz, 1825), Laird-Gompertz (Laird, 1964; Zweifel and Lasker, 1976), Richards (Richards, 1959), linear (Haddon, 2011), logistic (Ricker, 1975), Ratkowsky (Ratkowsky, 1986), Francis (Francis, 1988), and Cerrato (Cerrato, 1990). All analyses were conducted in Microsoft Excel (vers. 16.7; Microsoft Corp., Redmond, WA) by using Solver, an add-in tool available in Excel (Haddon, 2011). Growth models were run using SL as the measure for length to increase sample size in this study because some of the captured river herring had damaged caudal fins, making TL and FL unreliable or unattainable measures. However, past documentation of growth parameters for river herring were done with FL or TL. To directly compare this study's results with those of past studies, the von Bertalanffy growth function was run with FL and TL for each species; mean asymptotic lengths $\left(L_{\infty}\right)$ are reported in parentheses in the "Discussion" section when applicable for comparison with results of other studies.

The best-fit model was determined by using the AIC (Akaike, 1974; Hilborn and Mangel, 1997; Burnham and Anderson, 2002). The use of the AIC allows non-

\footnotetext{
10 Mention of trade names or commercial companies is for identification purposes only and does not imply endorsement by the National Marine Fisheries Service, NMFS.
}

nested models to be compared and over-parameterization of a model to be taken into context (Hilborn and Mangel, 1997). The AIC was then transformed to AIC weights to determine which model was furthest from the true AIC value (Burnham and Anderson, 2002).

An analysis of residual sum of squares was conducted on the best-fit model to determine if there are sex-specific differences in growth parameters. Finally, a likelihood ratio was used to test which growth parameters are responsible for any differences between sexes. The likelihood ratio is a chi-square distribution with degrees of freedom (df) that compares the sums of squares of the models for each combination of growth parameters by estimating each parameter individually through the growth model while holding some parameters constant and calculating the sums of squares for each combination of parameters.

\section{Results}

Alewife ( $n=1707$ ) were captured in tributaries of the Potomac River for 9 consecutive years from 2007 through 2015 , and 598 of these fish were dissected for aging. Blueback herring ( $n=1159)$ were captured in 2007 and 2008 and from 2011 through 2015, and 304 of them were dissected for aging. In 2015 , the catch of both species was an order of magnitude higher than the catch of any other year during this study (Fig. 2). Methods and locations of sampling were consistent from 2009 through 2015, except that Cameron Run was added from 2013 through 2015, resulting in the capture of 1 alewife, 6 alewife, and 16 alewife in each of those 3 years, respectively. Therefore, the increased catch of alewife in 2015 was not due to increased effort. 


\begin{tabular}{|c|c|c|c|c|}
\hline \multicolumn{5}{|c|}{$\begin{array}{l}\text { The equations used to convert between values of standard length (SL), fork } \\
\text { length (FL), and total length (TL) in millimeters for alewife (Alosa pseudo- } \\
\text { harengus) and blueback herring (Alosa aestivalis) captured from tributaries } \\
\text { of the Potomac River in northern Virginia during } 2007-2015 \text {. Also provided } \\
\text { are coefficients of multiple determination }\left(R^{2}\right) \text {, or proportions of variance, to } \\
\text { indicate the correlation between variables used to determine the equations. }\end{array}$} \\
\hline Species & Conversion & Equation & $n$ & $R^{2}$ \\
\hline Alewife & SL to FL & $F L=1.0076(S L)+18.832$ & 1056 & 0.920 \\
\hline Alewife & SL to TL & $T L=1.0922(S L)+31.529$ & 1002 & 0.873 \\
\hline Alewife & FL to TL & $T L=0.9852(F L)+33.807$ & 1001 & 0.968 \\
\hline Blueback & SL to FL & $F L=1.0208(S L)+14.675$ & 630 & 0.928 \\
\hline Blueback & SL to TL & $T L=1.1446(S L)+18.644$ & 630 & 0.930 \\
\hline Blueback & FL to TL & $T L=1.104(F L)+6.02$ & 630 & 0.972 \\
\hline
\end{tabular}

\section{Length-length relationship}

Alewife had a mean SL of $210.8 \mathrm{~mm}$ (standard deviation [SD] 13.57), mean FL of $231.2 \mathrm{~mm}$ (SD 14.25), and mean TL of $261.9 \mathrm{~mm}$ (SD 15.85). Blueback herring had a mean SL of $202.1 \mathrm{~mm}$ (SD 11.80), mean FL of $221.0 \mathrm{~mm}$ (SD 12.51), and mean TL of $250.0 \mathrm{~mm}$ (SD 14.00). The relationships between SL, FL, and TL were highly significant for alewife and blueback herring (with all proportions of variance, or coefficients of multiple determination, >0.85; Table 1).

\section{Aging}

Alewife Otoliths were collected from 574 alewife over 9 consecutive years (2007-2015), and readers agreed on all ages except for 1 alewife. Ages ranged from 2 to 7 years with a median age of 3 years for both females $(n=244)$ and males $(n=329)$. Scales could be read for 532 of the 574 dissected alewife. Scale aging revealed reader bias, particularly in younger ages. Fish aged as 2 and 3 years old from scale readings commonly had younger ages that the 2 readers agreed upon from their otolith analyses, and fish assigned ages of 5,6 , and 7 years from scale analyses commonly had older age estimates from otolith readings; however, for fish at ages of 4,6 , and 7 years based on scale readings, estimates were not statistically different from ages based on otolith analyses (Table 2). Biases in ages between scale and otolith readings were statistically different in the $\mathrm{McNe}$ mar's, Evans-Hoenig, and Bowker's tests: $P=0.0032$, $P=0.0089, P=0.0001$, respectively. Ages determined with the use of scales and otoliths agreed for $83.1 \%$ of the samples and were within 1 year of each other for an additional $15.0 \%$ of samples, with an ACV of $3.8 \%$, indicating that the ages were precise according to standards established by Campana (2001).

Blueback herring Blueback herring were sampled from 2007 through 2015, but none were captured in 2009 and 2010. Otolith readers agreed on ages for 285 of

\section{Table 2}

The number of samples for each comparison of ages between otolith and scale readings for alewife (Alosa pseudoharengus) captured between 2007and 2015 in the Potomac River in northern Virginia, with $t$-test statistics $(t)$ to indicate bias for each age. An asterisk $(*)$ indicates when the ages determined by reading scales were significantly different from the age determined by reading otoliths.

\begin{tabular}{|c|c|c|c|c|c|c|c|c|}
\hline \multirow[b]{2}{*}{ Otolith age } & \multicolumn{6}{|c|}{ Scale age } & \multirow[b]{2}{*}{$t$} & \multirow[b]{2}{*}{$P$} \\
\hline & 2 & 3 & 4 & 5 & 6 & 7 & & \\
\hline 2 & 16 & 22 & 1 & 1 & - & - & 6.51 & $<0.0001^{*}$ \\
\hline 3 & - & 222 & 20 & 2 & 2 & - & 4.60 & $<0.0001^{*}$ \\
\hline 4 & - & 10 & 140 & 8 & - & - & -0.47 & 0.6388 \\
\hline 5 & - & - & 14 & 49 & 2 & - & -3.21 & $0.0084^{*}$ \\
\hline 6 & - & - & 2 & 2 & 11 & 1 & -1.58 & 0.2824 \\
\hline 7 & - & - & - & 2 & 1 & 4 & -1.99 & 0.2824 \\
\hline
\end{tabular}




\begin{tabular}{|c|c|c|c|c|c|c|c|}
\hline \multicolumn{8}{|c|}{ Table 3} \\
\hline \multicolumn{8}{|c|}{$\begin{array}{l}\text { The number of samples for each comparison of ages between otolith and scale readings fo } \\
\text { blueback herring (Alosa aestivalis) captured in } 2007 \text { and } 2008 \text { and between } 2011 \text { and } 2015 \text { in } \\
\text { the Potomac River in northern Virginia, with } t \text {-test statistics }(t) \text { to indicate bias for each age } \\
\text { An asterisk }(*) \text { indicates when the ages determined by reading scales were significantly dif } \\
\text { ferent from the age determined by reading otoliths. }\end{array}$} \\
\hline \multirow[b]{2}{*}{ Otolith age } & \multicolumn{5}{|c|}{ Scale age } & \multirow[b]{2}{*}{$t$} & \multirow[b]{2}{*}{$P$} \\
\hline & 2 & 3 & 4 & 5 & 6 & & \\
\hline 2 & 41 & 13 & - & - & - & 4.10 & $0.0007^{*}$ \\
\hline 3 & - & 143 & 12 & - & - & 3.63 & $0.0151^{*}$ \\
\hline 4 & - & 1 & 32 & - & - & -1.00 & 0.6496 \\
\hline 5 & - & 3 & 2 & 8 & - & -2.55 & 0.0762 \\
\hline 6 & - & - & 1 & - & 3 & -1.00 & 0.6496 \\
\hline
\end{tabular}

287 samples. Ages ranged from 2 to 6 years, with a median age of 3 years for both females $(n=123)$ and males $(n=164)$. Scales could be read for 260 of 287 dissected blueback herring, with the ages of 2 and 3 years commonly overaged by readers and statistically biased on the basis of McNemar's, Evans-Hoenig, and Bowker's tests (all tests: $P<0.0001$; Table 3). Ages agreed between scale and otolith readings for $87.3 \%$ of the samples and were within 1 year of each other for an additional $10.8 \%$ of the samples. The ACV was $3.2 \%$, indicating that the aging of samples were precise (Campana, 2001).

\section{Growth models}

The best-fit model for alewife was the linear growth model, and the worst-fit model was the Richards growth model (Table 4). The best-fit model for blueback herring was the logistic growth model, and the worst-fit model was the linear growth model (Table 4). However, the AIC weights were only $10.6 \%$ and $10.5 \%$ different between the best-fit and worst-fit models for alewife and blueback herring, respectively (Table 4). For this reason, the von Bertalanffy growth function, the most traditionally used growth model, was used to

\section{Table 4}

Rank of Akaike's information criterion weights $(w)$ calculated for alewife (Alosa pseudoharengus) and blueback herring (Alosa aestivalis) based on sample size $(n)$, number of parameters $(k)$, sums of squares (SSQ), and Akaike's information criterion for model selection $\left(\mathrm{AIC}_{\mathrm{i}}\right)$ from each growth model used in this study.

\begin{tabular}{|c|c|c|c|c|c|c|c|}
\hline Species & Growth model & $n$ & $k$ & SSQ & $\mathrm{AIC}_{\mathrm{i}}$ & $w(\%)$ & Rank \\
\hline \multirow[t]{9}{*}{ Alewife } & Cerrato & 559 & 3 & 96,589 & 1702.954 & 11.432 & 5 \\
\hline & Francis & 559 & 3 & 96,589 & 1702.954 & 11.432 & 5 \\
\hline & Gompertz & 559 & 3 & 96,582 & 1702.936 & 11.533 & 3 \\
\hline & Laird-Gompertz & 559 & 3 & 96,582 & 1702.936 & 11.533 & 3 \\
\hline & Linear & 559 & 2 & 97,165 & 1702.398 & 15.093 & 1 \\
\hline & Logistic & 559 & 3 & 96,576 & 1702.921 & 11.621 & 2 \\
\hline & Ratkowsky & 559 & 3 & 96,589 & 1702.954 & 11.432 & 5 \\
\hline & Richards & 559 & 4 & 96,537 & 1704.823 & 4.490 & 9 \\
\hline & von Bertalanffy & 559 & 3 & 96,589 & $1,702.954$ & 11.432 & 5 \\
\hline \multirow[t]{9}{*}{ Blueback herring } & Cerrato & 285 & 3 & 34,956 & 828.756 & 13.170 & 4 \\
\hline & Francis & 285 & 3 & 34,956 & 828.754 & 4.914 & 8 \\
\hline & Gompertz & 285 & 3 & 34,955 & 828.751 & 13.170 & 4 \\
\hline & Laird-Gompertz & 285 & 3 & 34,955 & 828.751 & 13.193 & 2 \\
\hline & Linear & 285 & 2 & 36,429 & 831.863 & 2.782 & 9 \\
\hline & Logistic & 285 & 3 & 34,953 & 828.744 & 13.240 & 1 \\
\hline & Ratkowsky & 285 & 3 & 34,956 & 828.754 & 13.170 & 4 \\
\hline & Richards & 285 & 4 & 34,948 & 830.726 & 13.193 & 2 \\
\hline & von Bertalanffy & 285 & 3 & 34,956 & 828.754 & 13.170 & 4 \\
\hline
\end{tabular}






examine the difference between sexes. All of the models converged, indicating that enough data was available for the models to successfully run.

The von Bertalanffy growth parameters differed between alewife and blueback herring $(P<0.0001)$. Alewife grew faster and obtained larger sizes than blueback herring (Table 5). A likelihood ratio test confirmed the difference between species was not due to coincidence $\left(\chi^{2}=39, \mathrm{df}=3, P<0.0001\right)$; however, no single parameter was responsible for this difference.

For alewife, parameters between sexes were statistically different when the von Bertalanffy growth function was used $(P<0.0001)$. The models for both species show females growing faster than males and attaining larger values of $L_{\infty}$ (Table 5, Fig. 3A). The standardized residuals for the von Bertalanffy growth curve were randomly distributed, indicating that the model was a good fit (Fig. 3B). A likelihood ratio test confirmed that the difference between sexes was not due to coincidence $\left(\chi^{2}=229, \mathrm{df}=3\right.$, $P<0.0001$ ); however, differences were not significant between individual parameters.

For blueback herring, an analysis of residual sum of squares revealed that female blueback herring grew significantly larger and faster than males $(P<0.0001$; Table 5, Fig. 4A), and a likelihood ratio test confirmed the differences were significant $\left(\chi^{2}=138, \mathrm{df}=3, P<0.0001\right)$. Standardized residuals between the von Bertalanffy growth function and observed values were random (Fig. 4B). Differences between sexes were based on the interactions between the parameters of $L_{\infty}$ and growth rate coefficient $(K)\left(\chi^{2}=8, \mathrm{df}=2, P=0.02\right)$ and interactions between $L_{\infty}$ and the time (or age) at which the average length was zero $\left(t_{0}\right)$ (von Bertalanffy:



Figure 3

(A) Observed length at age for female (gray dots) and male (black plus signs) alewife (Alosa pseudoharengus) captured in the Potomac River between 2007 and 2015, with predicted length at age from von Bertalanffy growth models (solid lines). (B) Standardized residuals versus fitted values for the von Bertalanffy growth curves for female (gray dots) and male (black plus signs) alewife. 

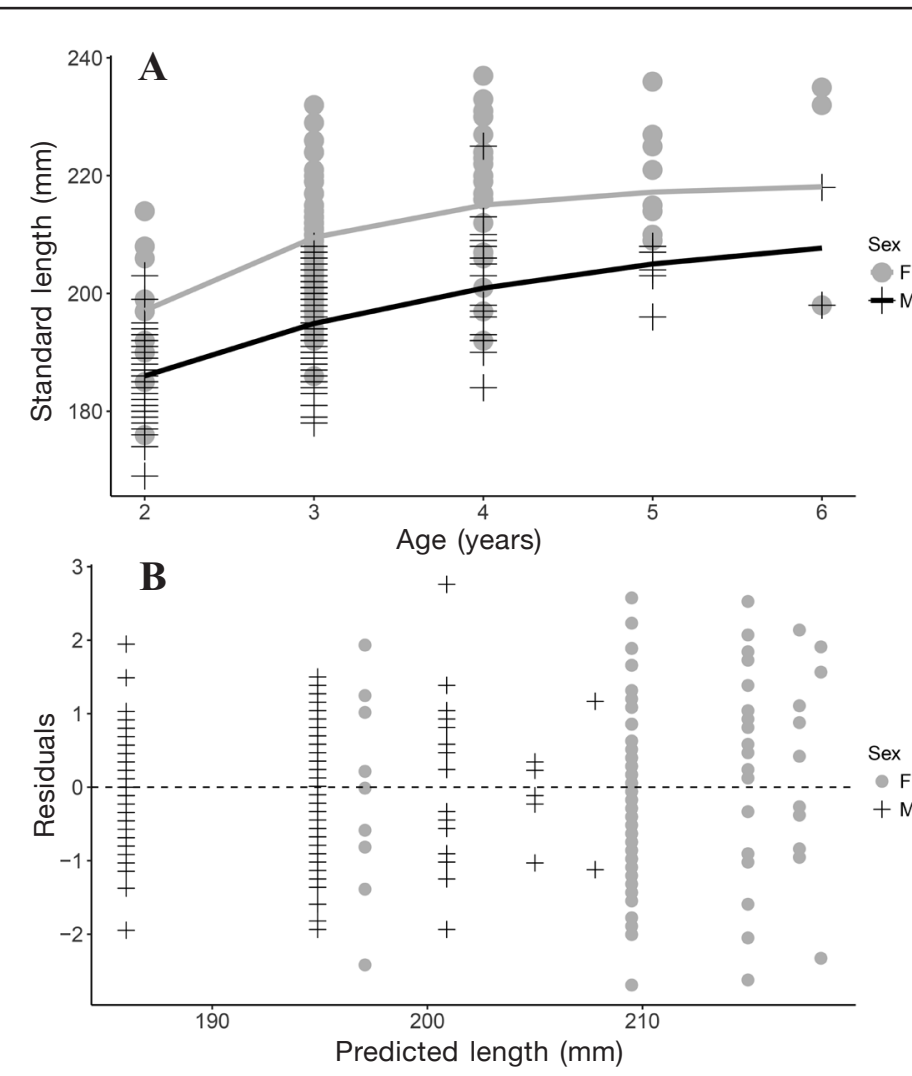

Figure 4

(A) Observed length at age for female (gray dots) and male (black plus signs) blueback herring (Alosa aestivalis) captured in the Potomac River in 2007 and 2008 and from 2011 through 2015 , with predicted length at age from von Bertalanffy growth models (solid lines). (B) Standardized residuals versus fitted values for the von Bertalanffy growth curves for female (gray dots) and male (black plus signs) blueback herring. alewife grew fastest and largest, followed by male alewife, then female blueback herring and male blueback herring. However, in the Albemarle Sound, North Carolina, female blueback herring grew faster and larger than male alewife. Fay et al. ${ }^{1}$ provided average length-atage data from multiples studies, information that indicates that growth rates of alewife and blueback herring were not consistent between studies (Fay et al. ${ }^{1}$ ). For example, in Georges Bank, alewife had a larger average length at age than blueback herring for every age, but in the Connecticut River larger average length varied between these species on the basis of age (Netzel and Stanek, 1966; Marcy, 1969; Fay et al. $\left.{ }^{1}\right)$. Why these differences in growth rates occurred between these studies is unclear. It could be due to differences in geography or time, given that both have been documented to affect growth of fish populations.

The estimates of $L_{\infty}$ for alewife $(273.9 \mathrm{~mm}$ FL) and for blueback herring (267.0-mm-FL) from this study are smaller than previously published estimates from other studies. The NOAA Northeast Fisheries Science Center conducted a bottom-trawl survey from 1973 through 1987 and used the survey data to estimate $L_{\infty}: 282.6 \mathrm{~mm} \mathrm{FL}$ for alewife and 267.0 $\mathrm{mm}$ FL for blueback herring (ASMFC, 2012). For both sexes, the $L_{\infty}$ also was smaller for individuals examined in this study than for individuals captured in the Saint John River in New Brunswick (male and female alewife: 292 and $310 \mathrm{~mm} \mathrm{FL;} \mathrm{male} \mathrm{and} \mathrm{female} \mathrm{blue-}$ back herring: 231 and $260 \mathrm{~mm}$ FL; Messieh 1977) and in New Hampshire rivers (male and female alewife: 305 and $322 \mathrm{~mm}$ TL; male and female blueback herring: 287 and $328 \mathrm{~mm}$ TL; ASMFC, 2012). The differences between estimates of $L_{\infty}$ were most likely due to a lack of older individuals captured in the Potomac River, a situation that can lead to a poor estimation of the $L_{\infty}$ (Hilborn and Walters, 1992).

Alewife and blueback herring historically have been aged up to 14 and 9 years, respectively (ASMFC, 2012), but the maximum ages for these species in this study were 7 and 6 years. A lack of representation of older fish in a data set can result from high adult mortality rates, gear selectivity, or underaging of fish (Francis, 1988). High adult mortalities in river herring have been linked to increased stress during spawning migrations, historical overfishing practices, and current bycatch of adult fish (Hightower et al., 1996; Greene et al. ${ }^{2}$; ASMFC, 2012). This pattern has been seen for other adult anadromous fishes as well (Dunton et al., 2015). The current moratoria for river herring have been in effect regionally only for 3 years; therefore, older river herring have been protected for a limited part of their life span.

The $K$ value was lower for alewife and male blue- et al., 1978; Fay et al. ${ }^{1}$; Klauda et al., 1991). In the Saint John River in New Brunswick, Canada, female
Females grew faster and larger than males for both species of river herring. Similar to the outcome of this study, previous studies have documented larger and faster-growing females for both species (Marcy, 1969; alewife grew faster and larger than blueback herring, a finding that also has been documented by previous studies (Netzel and Stanek, 1966; Messieh, 1977; Jones 
back herring in this study than for those in previous studies (Messieh, 1977; ASMFC, 2012), differences that could be due to a lack of smaller individuals in the previous studies. For this study, alewife ranging in age from 2 to 7 years and blueback herring ranging in age from 2 to 6 years were used; however, in both previous studies, river herring ranged from 3 years to more than 9 years (Messieh, 1977; ASMFC, 2012). When age- 2 individuals were removed from the analysis in this study, $K$ increased from 0.179 to $0.243 \mathrm{~mm} /$ year for alewife (both sexes combined) and from 0.525 to 0.697 $\mathrm{mm} /$ year for blueback herring (both sexes combined). One hypothesis for why age-2 individuals were available in this study and not in previous studies is that the populations could have spawned at earlier ages in this study because of years of overfishing, which has been documented in Atlantic cod (Gadus morhua) (Trippel, 1995), several Pacific salmon species (Ricker, 1981), and numerous other fish species (Darimont et al., 2009). Fishermen target large individuals within a population. With years of fishing pressure, a population adapts to spawning as smaller, younger individuals because individual fish that can spawn at smaller sizes are more likely to successfully spawn than slower maturing individuals (Ricker, 1981; Thorpe, 1993). A change in maturity schedules is important to document for estimating potential recruitment of a population and should be examined further.

The lack of ages from 0 to 1 years and ages $\geq 7$ years also could have contributed to the similarities between the different growth models tested within this study because the parameters in each model are correlated to each other (Hilborn and Walters, 1992; Campana, 2001; Allen and Gwinn, 2013). Missing younger and older fish of a population can make model estimation difficult because these 2 ends of a population can influence growth more than the part of a population at median ages (Campana, 2001). The younger and older ends of a population can also be the most difficult to obtain because of increased mortality for older individuals, anadromous species being collected during spawning runs only (as in this study), or age estimation being hardest for these categories (Campana, 2001; ASMFC, 2012; $\mathrm{ASMFC}^{8}$ ). Even in this study, when scales were used for aging, younger individuals were overaged and older individuals were underaged.

The ASMFC River Herring Ageing Workshop found that participating state agencies also overaged younger fish and underaged older fish when using scales $\left(\mathrm{ASMFC}^{8}\right)$. Many agencies base the methods for using scales to age river herring on the methods developed by Cating (1953) for American shad. Marcy (1969) developed transverse groove counts specific to river herring captured in Connecticut based on Cating's (1953) method. However, this method does not take geographical location into account as a factor on fish growth and scale formation (Duffy et al., 2011). The use of transverse grooves, outlined by Cating (1953) and Marcy (1969), to determine location of freshwater zones and the first 3 years of age resulted in inconsistencies be- tween ages in different geographical regions within the distribution of American shad (Duffy et al., 2011). Age validation with known-age river herring needs to be completed for each geographical region for the analysis of scales to be reliable as an aging technique for river herring $\left(\mathrm{ASMFC}^{8}\right)$. The ASMFC River Herring Ageing Workshop has developed protocols to standardize aging techniques and has started a reference collection for aging structures from different rivers throughout the East Coast of the United States (ASMFC ${ }^{8}$ ).

Using data sets with biased ages can result in poor population modeling and conflicting strategies for population management (Beamish and McFarlane, 1987; Bertignac and de Pontual, 2007; Katsanevakis and Maravelias, 2008; Tyszko and Pritt, 2017; Porta et al., 2018). Age biases can influence stock assessment by overestimating or underestimating growth or mortality, affecting policy decisions about a population (Beamish and McFarlane, 1987; Katsanevakis and Maravelias, 2008). Alewife in this study were more likely to be underaged by the use of scales, increasing the estimates for growth and mortality rates (Beamish and McFarlane, 1987). Management strategies for species that are not growing as fast as models indicate can lead to overfishing practices. Conversely, blueback herring were more often overaged when scales were used in this study. Therefore, growth and mortality predictions could be lower than real levels, possibly limiting the ability of management agencies to track how reactive a population is to fishing changes (Tyszko and Pritt, 2017). The ages presented here for this study are considered precise between readers on the basis of the $\mathrm{ACV}$, but there was no way to determine accuracy without the use of known-age individuals. Currently, no known-age samples for either species of river herring are available for use $\left(\mathrm{ASMFC}^{8}\right)$.

This study reveals the importance of validating aging techniques for species of river herring, as well as of continuing to monitor the ages and individual growth rates of the populations of alewife and blueback herring. Many management agencies are calling for an increase in run counts and abundance estimates of these populations (ASMFC, 2012, 2017). Documenting abundances of river herring is only a small component in understanding a population that may have dramatically changed over decades because of overfishing and degraded habitats. The additional age and growth estimates completed in this study provide information needed in the ongoing efforts to restore the once great fisheries that targeted these species.

\section{Acknowledgments}

Comments of 2 anonymous reviewers have improved the manuscript. We would like to acknowledge R. Jones for conception of the monitoring program and previous co-principal investigator $R$. Kraus for collection of the samples before 2011. We would like to thank M. Ogburn, C. Ahn, and K. Lewis for their insight into this 
project. Logistical support was provided by J. van der Ham and B. Bachman. This study was funded by Fairfax County through its Department of Public Works and Environmental Services and by Alexandria Renew Enterprises. Mention of trade names or commercial companies does not imply endorsement by the Potomac Environmental Research and Education Center, George Mason University.

\section{Literature cited}

Akaike, H.

1974. A new look at the statistical model identification. IEEE Trans. Auto. Control 19:716-723. Crossref

Allen, M. S., and D. Gwinn.

2013. Population models for assessment and management of inland striped bass fisheries. Am. Fish. Soc. Symp. 80:351-364.

ASMFC (Atlantic States Marine Fisheries Commission).

2012. River herring benchmark stock assessment. Stock Assess. Rep. 12-02. 2 vols. Atl. States Mar. Fish. Comm., Washington, D.C. [Available from website.]

2017. River herring stock assessment update. 2 vols. Atl. States Mar. Fish. Comm., Washington, D.C. [Available from website.]

Beamish, R. J., and G. A. McFarlane.

1987. Current trends in age determination methodology. In Age and growth of fish (R. C. Summerfelt and G. E. Hall, eds.), p. 15-42. Iowa State Univ. Press, Ames, IA.

Bertignac, M., and H. de Pontual.

2007. Consequences of bias in age estimation on assessment of the northern stock of European hake (Merluccius merluccius) and on management advice. ICES J. Mar. Sci. 64:981-988. Crossref

Besler, D. A.

1999. Utility of scales and whole otoliths for aging largemouth bass in North Carolina. Proc. Annu. Conf. SEAWFA 53:119-129.

Burnham, K. P., and D. R. Anderson.

2002. Model selection and multimodel inference: a practical information-theoretic approach, 488 p. SpringerVerlag, New York.

Campana, S. E.

2001. Accuracy, precision and quality control in age determination, including a review of the use and abuse of age validation methods. J. Fish Biol. 59:197-242. Crossref

Campana, S. E., and J. D. Neilson.

1985. Microstructure of fish otoliths. Can. J. Fish. Aquat. Sci. 42:1014-1032. Crossref

Campana, S. E., M. C. Annand, and J. I. McMillan.

1995. Graphical and statistical methods for determining the consistency of age determinations. Trans. Am. Fish. Soc. 124:131-138. Crossref

Cating, J. P.

1953. Determining age of Atlantic shad from their scales. Fish. Bull. 85:187-199.

Cerrato, R. M.

1990. Interpretable statistical tests for growth comparisons using parameters in the von Bertalanffy equation. Can. J. Fish. Aquat. Sci. 47:1416-1426. Crossref

Darimont, C. T., S. M. Carlson, M. T. Kinnison, P. C. Paquet, T. E. Reimchen, and C. C. Wilmers.

2009. Human predators outpace other agents of trait change in the wild. Proc. Natl. Acad. Sci. U.S.A. 106:952-954. Crossref

Duffy, W. J., R. S. McBride, S. X. Cadrin, and K. Oliveira.

2011. Is Cating's method of transverse groove counts to annuli applicable for all stocks of American shad? Trans. Am. Fish. Soc. 140:1023-1034. Crossref

Dunton, K. J., A. Jordaan, D. O. Conover, K. A. McKown, L. A. Bonacci, and M. G. Frisk.

2015. Marine distribution and habitat use of Atlantic sturgeon in New York lead to fisheries interactions and bycatch. Mar. Coast. Fish. 7:18-32. Crossref

Evans, G. T., and J. M. Hoenig.

1998. Testing and viewing symmetry in contingency tables, with application to readers of fish ages. Biometrics 54:620-629. Crossref

Francis, R. I. C. C.

1988. Are growth parameters estimated from tagging and age-length data comparable? Can. J. Fish. Aquat. Sci. 45:936-942. Crossref

Gompertz, B.

1825. XXIV. On the nature of the function expressive of the law of human mortality, and on a new mode of determining the value of life contingencies. Philos. Trans. R. Soc. Lond. 115:513-583. Crossref

Haddon, M.

2011. Modelling and quantitative methods in fisheries, $2^{\text {nd }}$ ed., 465 p. $\quad$ CRC Press, Boca Raton, FL.

Heino, M.

1998. Management of evolving fish stocks. Can. J. Fish. Aquat. Sci. 55:1971-1982. Crossref

Heino, M., and O. R. Godo.

2002. Fisheries-induced selection pressures in the context of sustainable fisheries. Bull. Mar. Sci. 70:639-656.

Hightower, J. E., A. M. Wicker, and K. M. Endres.

1996. Historical trends in abundance of American shad and river herring in Albemarle Sound, North Carolina. North Am. J. Fish. Manage. 16:257-271. Crossref

Hilborn, R., and C. J. Walters (eds.).

1992. Quantitative fisheries stock assessment: choice, dynamics and uncertainty, 570 p. Chapman and Hall, London.

Hilborn, R., and M. Mangel.

1997. The ecological detective: confronting models with data, 336 p. Princeton Univ. Press, Princeton, NJ.

Jessop, B. M.

1994. Homing of alewives (Alosa pseudoharengus) and blueback herring (A. aestivalis) to and within the Saint John River, New Brunswick, as indicated by tagging data. Can. Tech. Rep. Fish. Aquat. Sci. 2015, 22 p.

Jones, P. W., F. D. Martin, and J. D. Hardy Jr.

1978. Development of fishes of the mid-Atlantic Bight: an atlas of egg, larval, and juvenile stages. Vol. 1: Acipenseridae through Ictaluridae, 366 p. Biol. Serv. Prog., U.S. Fish Wildl. Serv., Washington, D.C.

Jones, R. C., D. P. Kelso, and E. Schaeffer.

2008. Spatial and seasonal patterns in water quality in an embayment-mainstem reach of the tidal freshwater Potomac River, USA: a multiyear study. Environ. Monit. Assess. 147:351-375. Crossref

Katsanevakis, S., and C. D. Maravelias.

2008. Modelling fish growth: multi-model inference as a better alternative to a priori using von Bertalanffy equation. Fish Fish. 9:178-187. Crossref

Klauda, R. J., S. A. Fischer, L. W. Hall Jr., and J. A. Sullivan. 1991. Alewife and blueback herring; Alosa pseudoharen- 
gus and Alosa aestivalis. In Habitat requirements for Chesapeake Bay living resources, rev. ed. (S. L. Funderburk, J. A. Mihursky, S. J. Jordan, and D. Riley, eds.), p. 10.11-10.29. Living Resour., Chesapeake Bay Prog., Annapolis, MD.

Laird, A. K.

1964. Dynamics of tumor growth. Br. J. Cancer 18:490-502. Crossref

Law, $\mathrm{R}$

2000. Fishing, selection, and phenotypic evolution. ICES J. Mar. Sci. 57:659-668. Crossref

Loesch, J. G.

1987. Overview of life history aspects of anadromous alewife and blueback herring in freshwater habitats. Am. Fish. Soc. Symp. 1:89-103.

Loesch, J. G., and W. A. Lund.

1977. A contribution to the life history of the blueback herring, Alosa aestivalis. Trans. Am. Fish. Soc. 106:583-589. Crossref

Marcy, B. C., Jr.

1969. Age determinations from scales of Alosa pseudoharengus (Wilson) and Alosa aestivalis (Mitchill) in Connecticut waters. Trans. Am. Fish. Soc. 98:622630. Crossref

Messieh, S. N.

1977. Population structure and biology of alewives (Alosa pseudoharengus) and blueback herring (A. aestivalis) in the Saint John River, New Brunswick. Environ. Biol. Fish. 2:195-210. Crossref

Netzel, J., and E. Stanek.

1966. Some biological characteristics of blueback herring and alewife from Georges Bank, July and October, 1964. Intl. Comm. Northwest Atl. Fish. Res. Bull. $3: 106-110$.

Ogle, D. H.

2015. Age comparisons. In Introductory fisheries analyses with R, p. 75-86. CRC Press, Boca Raton, FL.

Porta, M. J., R. A. Snow, and D. E. Shoup.

2018. Comparison of saugeye age estimates and population characteristics using otoliths and dorsal spines. JSEAWFA 5:23-29.

Quinn, T. J., and R. B. Deriso.

1999. Quantitative fish dynamics, 560 p. Oxford Univ. Press, New York.

Ratkowsky, D. A.

1986. Statistical properties of alternative parameterizations of the von Bertalanffy growth curve. Can. J. Fish. Aquat. Sci. 43:742-747. Crossref
Richards, F. J.

1959. A flexible growth function for empirical use. J. Exp. Bot. 10:290-301. Crossref

Ricker, W. E.

1975. Computation and interpretation of biological statistics of fish populations. Bull. Fish. Res. Board Can. 191, $382 \mathrm{p}$.

Ricker, W. E.

1981. Changes in the average size and average age of Pacific salmon. Can. J. Fish. Aquat. Sci. 38:16361656. Crossref

Schlick, C. J. C.

2016. Life history traits and population dynamics of river herring, alewife Alosa pseudoharengus and blueback herring Alosa aestivalis in Potomac River tributaries. Ph.D. diss., 254 p. George Mason Univ., Fairfax, VA. [Available from website.]

Thorpe, J. E.

1993. Impacts of fishing on genetic structure of salmonid populations. In Genetic conservation of salmonid fishes (J. G. Cloud and G. H. Thorgaard, eds.), p. 67-80. Plenum Press, New York.

Trippel, E. A.

1995. Age at maturity as a stress indicator in fisheries: biological processes related to reproduction in northwest Atlantic groundfish populations that have undergone declines. BioScience 45:759-771. Crossref

Tuckey, T. D., and J. E. Olney.

2010. Maturity schedules of female American shad vary at small spatial scales in Chesapeake Bay. North Am. J. Fish. Manage. 30:1020-1031. Crossref

Tyszko, S. M., and J. J. Pritt.

2017. Comparing otoliths and scales as structures used to estimate ages of largemouth bass: consequences of biased age estimates. North Am. J. Fish. Manage. 37:10751082. Crossref

von Bertalanffy, L.

1938. A quantitative theory of organic growth (inquiries on growth laws. II). Hum. Biol. 10:181-213.

Wang, H.-Y., and T. O. Höök.

2009. Eco-genetic model to explore fishing-induced ecological and evolutionary effects on growth and maturation schedules. Evol. Appl. 2:438-455. Crossref

Wharton, J.

1957. The bounty of the Chesapeake, 78 p. Univ. Press Virg. Charlottesville, VA.

Zweifel, J. R., and R. Lasker.

1976. Prehatch and posthatch growth of fishes-a general model. Fish. Bull. 74:609-621. 